\title{
Pierangelo Buongiorno (ed.), Senatus consultum ultimum e stato di eccezione. Fenomeni in prospettiva, (Acta Senatus, ser. B, vol. 8), Franz Steiner Verlag, Stuttgart 2020, 195 pp; ISBN 978-3-515-12647-2
}

It usually takes many years to complete major group projects, and their results appear only several years after this. It is therefore exceptional for scholars to be able to make use of an entire series of publications closely related to the project before its completion. This is the case with the PaRoS (Palingenesie der römischen Senatsbeschlüsse (509 v. Chr.284 n. Chr.) project, commenced in 2015 at the University of Münster under the direction of Pierangelo Buongiorno. Although no volumes in the series containing the texts of the senatus consulta accompanied by commentary have yet been published (Series A), in the parallel series of publications (Series B), titled Studien und Materialen, eight have already been issued since 2017, with the next one in preparation.

The most recently published volume contains materials from a one-day conference that took place on 17 July 2019 at the University of Münster. In addition to a brief introduction by Buongiorno ("Riflessioni introduttive," pp. 7-10), it features six studies of legal and historical issues of the Senate decrees, which are referred to as senatus consultum ultimum $(=\mathrm{SCU})$ or senatus consultum servandae rei publicae causa. The authors of these studies, published (with one exception) in Italian, are mainly Italian scholars, both historians of Roman law and experts on the history of ancient Rome.

We know that the Roman senators first passed such a decree in 121 BCE. It was directed against Gaius Gracchus and his supporters (Cic., Cat. 1.4; Phil. 8.14; Plut., C. Gracchus 25.3). In the last century of the existence of the Republic, similar decrees were made at least 17 times, always in a situation of threat to the state's internal security. The practice and circumstances in which they were undertaken as well as their legal consequences have long been the subject of numerous analyses and interpretations from historians and historians of Roman law. Yet the articles included in this volume tackle not just these issues, but also the ways in which Roman legal institutions involved in protecting the state from the internal threat have influenced the views of lawyers and philosophers in modern and contemporary times.

Roberto Scevola's extensive study ("Senatus consultum ultimum. Orientamenti interpretative e questioni aperte," pp. 11-66) presents the current state of the debate on SCUs. He devotes most attention to the scale of Roman violations of civic liberties through the resolutions contained in the SCUs as well as to presenting the latest legal interpretations of the consequences of their application. In recent years, new aspects have been introduced to the discussion on SCUs by three scholars in particular: Roberto 
Fiori (pp. 51-56), Giorgio Agamben (pp. 56-58) and Luigi Garofalo (pp. 59-61), whose views and findings the author discusses at length.

Chiara Carsana's article ("Senatus consulta servandae r. p. causa nel II sec. a.C.," pp. 67-84) focuses on the Senate's first decrees concerning protection of the state's security from internal threats, analysed in terms of Roman historiographical tradition. In her opinion, they differ from those undertaken during the 1st century BCE, as their main objective was to defend the existing socio-political order.

Mario Varvaro's study (“Senatus consultum 'ultimum' und Erklärung zum Staatsfeind zwischen Recht, Rhetorik und Politik im spätrepublikanischen Rom,” pp. 85-108) concentrates on the legal situation of the citizen protected by ius provocationis in the light of the SCU decrees or when declared a public enemy by the Senate, because before introduction of the institution of the SCU, in a situation of threat, the role of defender of the state and order fell to the dictator, and civil rights were suspended. Making use of Cicero's works, Varvaro concludes that given the lack of clear criteria to determine when a citizen should be regarded as an enemy, the Senate could abuse this formula in a political struggle, while also restricting civil rights. ${ }^{1}$ Although SCUs did not have legal authority but were only a recommendation, ${ }^{2}$ this did not stop senators from abusing their rights in a political struggle (pp. 102f.).

The next two texts concern the influence of the institution of the SCU and Roman regulations on defence of domestic security on legal as well as philosophical conceptions in modern and contemporary times. Ulrico Agnati ("Rousseau e l'emergeza. Tra diritto pubblico romano e costituzioni democratiche," pp. 109-146) analyses Jean-Jacques Rousseau's views on forms of the state's reactions to threat and its functioning during a state of emergency, as expressed in Chapter 6 of the fourth book of The Social Contract. Piero Marino ("La misura dell'eccezione. Iustitium e teologia politica," pp. 147-160), meanwhile, analyses Agamben's views on the legal aspect of the state of emergency in the context of the modern day, showing that an important inspiration for him were not only the conceptions of Carl Schmitt contained in his works on dictatorship and political theology published in the 1920s, but also the Roman legal institution of iustitium.

Maria Teresa Schettino's paper ("Riflessioni in forma di bilancio sul senatus consultum servandae rei publicae causa. Periodizzazione di un istituto giuridico," pp. 161185) complements and summarises the findings of the other authors. The author emphasises the distinct evolution of the nature of the SCU in the period of its application, i.e. between 121 and $40 \mathrm{BCE}$, and especially after $63 \mathrm{BCE},{ }^{3}$ and the use of this legal

1 "Eine Verfassung im modernen Sinne hatten die Römer nich und mangels einer gesetzlichen Festsetzung der Kriterien, die einen Bürger zum Staatsfeind machten, konnten die Senatoren eine Entscheidung treffen, die ohne jede Kontrolle blieb, auch wenn sie willkürlich war. Aber das Notstandsrecht des Senats war kein Notstandstandsrecht des ganzen Staats" (p. 100).

2 "Ein Senatsbeschluss war aber kein Gesetz, sondern nur eine Aufforderung. Wie jeder andere Senatsbeschluss wure er im Konjunkiv ('Videant consules"' etc.) und nich im Imperativ formuliert. Die Konsuln und andere Magistrate waren daher nicht gezwungen, seinen Inhalt zu vollstrecken. Mag der Senatsbeschluss auch einer politischen Vorgabe nahekommen, hat er dennoch keinerlei gesetzliche Kraft" (p. 101).

3 “.... il 63 a.C. sembra rappresentare un punto di svolta e, se l'uso del $s c u$. si incrementò nella seconda metà del secolo, i contesti della sua appilcazione erano diversi rispetto a quelli originari provocando una mutazione della natura giuridica di quest'istituto.” (p. 180) 
institution as a tool in the political battle solely within the ordo senatorius. ${ }^{4}$ This function is demonstrated by the considerable frequency of application of the SCU and the circumstances in which it was used in the 1 st century BCE. A useful addition to this article is a list of all 18 SCUs along with data on the individuals against whom they were directed, the senatorial officials responsible for implementing them, and the sources providing the information on each decree (pp. 183-185).

Reading this book leaves no doubt that its authors have added many valuable observations and interpretations to the debate on the institution of senatus consultum ultimum and its place in Rome's political life in the final century of the Republic's existence. It can certainly be recommended to general historians as well as historians of Roman law researching this period in the history of ancient Rome.

Edward Dąbrowa

iD http:/orcid.org/0000-0002-9324-9096

Jagiellonian University in Kraków

4 "I provvedimenti di scu. non colpivano cittadini qualsiasi, al contrario si trattava di senatori, e, tranne qualche rara eccezione, di magistrati o promagistrati nell'esercizio della loro carica. Nell'uso di tale decreto vi fu una strumentalizzazione politica dovuta al fatto che esso coinvolgeva sediziosi, o ritenuti tali, che non appartenevano sola al popolo, ma alla stessa classe politicha, tacciati di essere sobillatori di una rivolta il cui obiettivo principale era il senato o una parte consistente di senatori. La salus rei publicae fu fatta coincidere con la salus senatus, che riuniva tutti gli esponenti politici romani; sulla base di questa equivalenza lo stesso senato ritenne di potersi arrogare, non senza discussioni o divergenze al suo interno, il diritto di adottare il procedimento più efficace, che fu identificato nel scu." (pp. 172-173) 